\title{
Afscheid van Herman van Rossum als voorzitter van de NVMO
}

Tijdens de afsluitende sessie van het jaarlijkse congres van de Nederlandse Vereniging voor Medisch Onderwijs (NVMO) werd op 15 november 2002 stilgestaan bij het afscheid van Herman van Rossum als voorzitter van de vereniging. Herman trad in februari 1997 aan als voorzitter en volgde daarmee Lennart Bouman op. Herman heeft zich in de afgelopen jaren vooral toegelegd op de professionalisering van de vereniging. Ooit begonnen als een kleine club van docenten die geïnteresseerd waren in medisch onderwijs, is de NVMO immers in dertig jaar uitgegroeid naar een vereniging met meer dan 700 leden, die een eigen Tijdschrift voor Medisch Onderwijs (TMO) uitgeeft, cursussen voor docenten verzorgt en een jaarlijks nationaal congres op de kalender zet dat in Nederland en Vlaanderen op het gebied van onderwijs aan studenten geneeskunde toonaangevend is geworden. Kortom, een vereniging die zichzelf zichtbaar heeft gemaakt. Onder leiding van Herman is aandacht besteed aan de professionalisering van zowel het bestuur als de structuur van de vereniging, en door gebruik te maken van het instrument beleidsdagen zijn deze veranderingen voorbereid en uitgevoerd. Het uitnodigen van een klankbordgroep tijdens de beleidsdagen zorgde voor een breed draagvlak binnen de vereniging. Daarnaast had Herman veel aandacht voor de professionalisering van docenten en heeft hij met zorg de overgang van ODOS naar NVMO-cursussen begeleid.
Bij zijn vertrek laat Herman een bloeiende en gezonde vereniging achter, die klaar is om zich verder te manifesteren in medisch onderwijsland. Met een uitgesproken ambitie om binnen enkele jaren te gaan groeien naar 2500 leden, heeft hij zijn opvolger Albert Scherpbier met een duidelijk streefdoel op pad gestuurd. Het bestuur wil Herman nogmaals van harte bedanken voor de inzet en toewijding aan de NVMO in de afgelopen zes jaar.

Peter de Jong

Lid Dagelijks Bestuur NVMO 